\title{
Lima Barreto e o romance: crítica e crise
}

Carmem Lúcia Negreiros de Figueiredo

RESUMO: $\mathrm{O}$ artigo analisa o romance Recordações do escrivão Isaías Caminha, de Lima Barreto (1881-1922), apontando princípios formais presentes na obra, indicadores de uma nova realização estética que não se coaduna, plenamente, com o romance realista do século XIX. Por isso, propõe nova abordagem, ou moldura, para a obra que, de partida, considera a crise da subjetividade e da capacidade de narrar, coerente com a atmosfera das primeiras décadas do século $x x$.

PALAVRAS-CHAVE: Lima Barreto, romance, crise.

ABSTRACT: This article analyzes the novel Recordações do escrivão Isaías Caminha by Lima Barreto (1881-1922), pointing out formal principles in the work, indicators of a new aesthetic achievement that does not fully accord with the realist novel of the nineteenth century. Therefore, it proposes a new approach or frame for the work, which, from the start, considers the crisis of subjectivity and the ability to narrate consistent with the atmosphere of the early decades of the twentieth century.

KEYWORDS: Lima Barreto, novel, crisis. 
Os termos "crítica" e "crise" são frequentes nos estudos sobre a obra de Lima Barreto (18811922), especialmente referindo-se ao romance Recordações do escrivão Isaías Caminha. Ainda hoje, predomina a tendência de vincular esse romance à intenção autobiográfica, com a finalidade de denúncia sobre os entraves da vida literária à carreira do escritor; outros justificam o viés autobiográfico também como denúncia dos preconceitos que criaram barreiras e dificuldades à ascensão social de jovens mulatos, ainda que talentosos.

É preciso reconhecer que é difícil evitar esse viés interpretativo ante um texto que incita tal tipo de leitura, ainda que o compromisso autobiográfico não se cumpra e o teor ficcional não permita estabelecer uma clara correlação entre o narrador e seu criador. Seria, então, esse romance um equívoco do autor, a meio caminho entre ficção e autobiografia? A escolha de se lançar literato com tal obra significa somente a opção de praticar a literatura como denúncia e crítica social?

A expressão 'crise', por sua vez, vincula-se ao romance porque, para alguns críticos e leitores, a obra seria uma tentativa frustrada de realizar, no Brasil, um romance realista como os de padrão europeu do século XIX, cujos títulos significativos foram as obras de Stendhal, Balzac e Flaubert. A crise, nesse caso, relaciona-se a uma espécie de fratura de forma ou incapacidade de realização estética de um bom romance, apesar da tentativa e grande esforço de Lima Barreto.

Minha intenção, aqui, é pensar o romance Recordações do escrivão Isaías Caminha como uma crítica ao próprio gênero romance e sua possibilidade de narrar, concomitante e coerente à expressão da crise do sujeito, num efervescente contexto cultural que diluiu as marcas rígidas de tempo e espaço, nas primeiras décadas do século xx.

\section{CRISE DA SUBJETIVIDADE}

O questionamento acerca da subjetividade e da autonomia da consciência realiza-se sob muitas perspectivas e, desde a primeira metade do século XIX, muitos fatores contribuíram para tornar o indivíduo, simultaneamente, objeto de investigação e produtor de conhecimento. Entre eles, estão os debates, pesquisas e experiências que marcaram a passagem da óptica geométrica, vigente até o século XVIII, para a óptica fisiológica, que dominou os debates científicos e filosóficos sobre a visão e o olhar.

Um marco importante nesse processo foi a publicação de Manual da fisiologia humana, de Johannes Müller, em 1833, com o relato da nova experiência de um observador diante da luz, separada de qualquer ponto de referência estável, fonte ou origem; suas 
pesquisas e estudos conferem importância ao corpo compreendido como um conjunto de processos e atividades diversificados, "gerenciados por quantidades mensuráveis de energia e trabalho". A ilusão referencial é revelada e a pesquisa de Müller avança para a afirmação de uma relação arbitrária entre estímulo e sensação, apresentando papel relevante ao corpo para a apreensão do visível, para a organização da experiência sensorial. O conjunto de estudos permite delinear novos perfis de observador e identidade, tão instáveis e móveis quanto a visão e as sensações. "A visão é redefinida como capacidade de ser afetado por sensações que não têm ligação necessária com um referente."2

Entre relatos de pesquisas, experimentos, descobertas e a intensificação da vida sensorial, no cotidiano, aflora a noção de sujeito como estrutura composta sobre a qual diferentes técnicas e forças poderiam produzir, ou sugerir, diversas experiências, todas igualmente "realidades". Cada vez mais, a ideia da visão subjetiva afirma-se como um processo "em que o sujeito é, simultaneamente, objeto de controle e normalização".

Se o termo 'sensação' passa a sugerir efeitos na consciência (dor, calor, cores, luzes, olfato), a percepção passa a ser entendida como uma qualidade dos sentidos. Até a noção do "eu", tão marcadamente presente na mente introspectiva, passa a ser compreendida pelos filósofos como uma sequência ou recordação de sensações - "um padrão recorrente de sensações, algumas das quais desencadeadas por estímulos orgânicos internos e outros pelo ambiente". ${ }^{4}$ Assim, "a percepção não é somente uma relação passiva, ótica; ela também molda nosso comportamento, nosso humor, até mesmo nossa ação, quer por um instante, quer por um período maior". ${ }^{5}$

Nesse contexto, a cidade, com suas luzes, surpresas, sustos, vitrines, multidões e veículos, torna o sujeito atento e ávido pela riqueza e aspecto cambiante do meio urbano, com inúmeros estímulos visuais e sensações quase mágicas. A mobilidade do olhar, com indivíduos em constante deslocamento, apreendendo ambiências, diversas e simultâneas, e servindo-se de inventos ópticos variados para ampliar a capacidade perceptiva, torna a visão quase um fim em si mesma, de dimensão estética, para

\footnotetext{
1. CRARY, J. Técnicas do observador. Trad. Verrah Chamma. Rio de Janeiro: Contraponto, 2012, p. 91.

2. Id., p. 93.

3. Id., p. 93 .

4. Shapiro, M. Impressionismo: reflexões e percepções. Trad. Ana Luiza Dantas Borges. São Paulo: Cosac Naify, 2002, p. 48.

5. Id., p. 60.
} 
ser usufruída sem uma causa, justificativa ou consequência. O viés de temporalidade também redimensiona a percepção, valorizando o instante e o impacto que passa a produzir sobre os sentidos, sem a moldura da explicação racional ou do anteparo da causalidade, da utilidade.

Já na segunda metade do século XIX, há certa "volúpia do olho", ${ }^{6}$ com intenso culto à visão nas artes e na vida urbana, "um deleite cultivado com o visual por si só, e uma abundância de novos meios inventados para sua satisfação"? Além disso, "a atenção flutuante do indivíduo dirigida por um impulso caprichoso ou uma curiosidade" ${ }^{\text {p }}$ produz um interessante alinhamento entre as visões de artista - na pintura, fotografia e literatura - e a atividade visual cotidiana dos espectadores em deslocamento pelas cidades.

Pesquisas e experimentos revelam, ainda, o teor imperfeito e inconstante de nosso aparato visual, suscetível a procedimentos externos de manipulação e estímulo, com capacidade de gerar experiências, em diversos níveis, para o indivíduo. ${ }^{9}$ Descobertas e estudos acerca da pós-imagem - da presença da sensação na ausência de um estímulo - levam à produção de uma variedade de técnicas e certo desenraizamento da visão, em relação ao sistema representacional vigente até o século XVIII.

A segunda metade do século XIX, especialmente, cria o "grande comércio de imageria coletiva", momento em que se forma "uma solidariedade entre as operações da arte, as formas de imageria e a discursividade dos sintomas". ${ }^{10}$ Nesse contexto, formamse os principais discursos para interpretar os efeitos das imagens sociais e mercantis sobre os indivíduos, as relações sociais e a cultura.

A realidade urbana adquire uma condição mágica pela transferência da mercadoria, de lojas e vitrines, para o espetáculo das ruas, com a multidão extasiada. Nessa realização do capitalismo como cultura, tudo que é desejável - sexo, prestígio social, moda, poder - transforma-se em mercadoria apresentada como fetiche, em exposição, para a massa de espectadores e ávidos consumidores. Simultaneamente, dá-se a valoração extrema da experiência visual, com mobilidade e permutabilidade sem precedentes, ligada a técnicas para

\footnotetext{
6. Id., p. 166.

7. Id., p. 168

8. Id.

9. CRARY, op. cit.

10. RAnCière, J. O destino das imagens. Trad. Mônica Costa Netto. Rio de Janeiro: Contraponto, 2012, p. 26.
} 
fixar a atenção e impor a homogeneidade. "O consumidor real torna-se consumidor de ilusões. A mercadoria é essa ilusão efetivamente real, e o espetáculo é sua manifestação geral."

O fascínio mágico do Moderno é exercido nas ruas, nas vitrines, na imprensa, na moda, em forma de espetáculo que inspira os homens ao consumo de imagens da modernidade. Com as imagens-mercadorias, a imaginação fixa-se no cotidiano, por meio de etiquetas que anunciam sucesso, felicidade e beleza, e vendem solidão, desejos frustrados e perda de identidade, que se dilui nos objetos. Estes parecem ganhar vida autônoma absorvendo os indivíduos, fragmentados e dispersos pelas cidades e seus centros de consumo.

Marx ${ }^{12}$ como muitos outros filósofos e artistas, observa a separação dos sentidos e justifica-a como produto das relações de propriedade no âmbito do capitalismo. A imagem do "caleidoscópio", que coincide, para muitos artistas e intelectuais, com a variação e dinamismo da modernidade, é utilizada por ele para exemplificar o oposto: não a variação, mas a simétrica repetição que se apresenta ao espectador, equivalente ao efeito do paradigma industrial, com sua produtividade e eficiência, na oferta de bens de consumo. Em outras palavras, a produção repetida e mecânica das mesmas imagens, que geram uma sedutora e fantasmagórica visão do real, garantida não somente pela disseminação em massa das técnicas de ilusão, pela reeducação dos sentidos e sua alienação, mas, sobretudo, pelas relações de propriedade.

A propriedade privada tornou-nos tão estúpidos e unilaterais que um objeto só é nosso quando o temos, quando existe para nós como capital ou quando é imediatamente possuído, comido, bebido, vestido, habitado, em resumo, utilizado por nós. [...] Em lugar de todos os sentidos físicos e espirituais apareceu assim a simples alienação de todos esses sentidos, o sentido do ter. O ser humano teve que ser reduzido a esta absoluta pobreza, para que pudesse dar à luz a sua riqueza interior partindo de si. ${ }^{13}$

O observador descentrado, a dispersão da visão, a separação dos sentidos e sua alienação são exigências do econômico, que necessita da rápida coordenação do olhar e conhecimento preciso da capacidade óptica e sensorial humana.

\footnotetext{
11. Debord, G. A sociedade do espetáculo. Trad. Estela dos Santos Abreu. Rio de Janeiro: Contraponto, 1997, p. 33

12. MARX, K. Manuscritos econômico-filosóficos. 3. ed. Trad. José Carlos Bruni et al. São Paulo: Abril Cultural, 1985.

13. Id., p. 11.
} 
No turbilhão de pesquisas e práticas culturais da segunda metade do século XIX, Nietzsche ${ }^{14}$ questiona a possibilidade de se considerar a realidade fixa e estável, a partir de leis gerais fundadas no sujeito; ainda, ataca a supremacia da consciência e a pretensão, a ela atribuída, de domínio e conhecimento pleno de como as ações humanas são produzidas. O filósofo pensa a consciência como a parte de um indivíduo que recebe estímulos e responde a eles a partir de hábitos e antigas interpretações ou marcas mnêmicas. Assim, procura eliminar a distinção entre físico e psíquico, afirmando que os processos psicológicos teriam base neurofisiológica.

Nessa perspectiva, o "eu" torna-se "uma síntese conceitual que permite escamotear relações de forças" ${ }^{15}$ ou "um efeito de relações de domínio e obediência entre forças ${ }^{16}$ e Nietzsche ${ }^{17}$ realiza a destruição da unidade do sujeito, fundada na unidade da consciência e induzida pela função gramatical do sujeito.

É essencial que não nos enganemos a respeito do papel da 'consciência': Ela é a nossa relação com o 'mundo exterior' que ela desenvolveu. Por outro lado, a direção, respectivamente o resguardo e a cautela com respeito ao jogo conjunto das funções corporais, não nos vem à consciência; [...] Em suma: aquilo que se torna consciente está sob relações causais que nos são inacessíveis - a sequência de pensamentos, sentimentos, ideias na consciência não exprime nada a respeito do fato de que essa sequência é uma sequência causal: mas, aparentemente, em grau superlativo é assim. Sobre essa aparência fundamos todas as nossas representações de espírito, razão, lógica etc. [...] Habitualmente, toma-se a consciência mesma como sensorium-geral e instância superior: todavia, ela é apenas um meio de comunicação: ela desenvolveu-se nas relações e com respeito a interesse de relações [...]. 'Relações' são aqui entendidas também como as impressões do mundo externo e, de nossa parte, as reações necessárias no caso; da mesma maneira como são aqui entendidos os nossos efeitos no exterior. A consciência não é a condutora, mas um órgão de condução. ${ }^{18}$

14. Nietzsche, F. A vontade de poder. Trad. Marcos Sinésio P. Fernandes e Francisco José D. de Moraes. Rio de Janeiro: Contraponto, 2008.

15. marton, S. "Nietzsche: consciência e inconsciente". In: Extravagâncias. Ensaios sobre a filosofia de Nietzsche. São Paulo: Unijuí/Discurso Editorial, 2000, p. 140.

16. GIACOIA, O. Nietzsche como psicólogo. São Leopoldo: UNISINOS, 2001, p. 69.

17. NIETZSCHE, F., op. cit.

18. Id., p. 275.

146 • FIGUEIREDO, Carmem Lúcia Negreiros de. Lima Barreto e o romance... 
A consciência, pois, apoia-se sobre um conjunto de forças cuja completude e complexidade não domina e até desconhece. Para Nietzsche, o conceito sintético do "eu" reúne uma pluralidade de vivências e estados psíquicos numa unidade aparente, criada pela consciência e compreendida como um órgão de condução entre as impressões do mundo externo e as reações necessárias aos estímulos e impressões recebidos. O "eu" é produto da conscientização daquele efeito de comando e da disposição anímica sobre as quais se funda a convicção, ou crença, de se possuir domínio sobre si mesmo, como causa para todo fazer.

Nosso mau costume de tomar como essência um símbolo da memória, uma forma abreviada, e, finalmente, tomá-lo como causa [...]. Estabelecer uma espécie de perspectiva no ver, por sua vez, como causa do próprio ver: esse foi o passe de mágica na invenção do 'sujeito', do 'eu'.19

Para o filósofo, o sujeito é compreendido como multiplicidade de forças e relações; nas suas palavras, "minha hipótese: o sujeito como multiplicidade". ${ }^{\circ}$

A crítica à subjetividade e ao privilégio da consciência constitui um processo de confluência entre os resultados de pesquisas e experimentos sobre a visão, a intensificação da exigência sensorial na realidade urbana e as reflexões sobre o sujeito na filosofia. Nela, não há uma negação da subjetividade, mas sua projeção em novo lugar,

não mais como constituidora do conhecimento e da ação para tornar-se algo constituído em esferas que não estão ao seu alcance (o inconsciente em Freud, a práxis histórica em Marx e a vontade de poder em Nietzsche). Freud, Nietzsche e Marx revelam [...] a 'realidade' como construção imaginária da consciência [...]. ${ }^{21}$

A modernidade do século XIX, portanto, já questiona verdades e identidades fixas, imutáveis. Um indivíduo adaptável, em movimento, cujo corpo é dotado de novos padrões, passa a ser significativo para compreender a profusão de signos e imagens que fascinam e atemorizam. Nesse complexo movimento de pensamento e cultura, estaria

19. Id., p. 284 .

2o. Id., p. 263.

21. CHAuí, M. S. “A destruição da subjetividade na filosofia contemporânea”. Jornal de Psicanálise, São Paulo, v. 8, n. 20, p. 30, 1976. 
um escritor interessado somente em relatar suas desventuras e dilemas, com finalidade exemplar e denunciadora, por meio de um texto ficcional?

Escritor, e também intelectual, observador do fragmentado e, aos poucos, desfamiliarizado espaço urbano, crítico do cotidiano e da consequente intensificação desmedida da vida sensorial que projeta seus efeitos nas atitudes e valores dos indivíduos, além de leitor contumaz de Nietzsche ${ }^{22}$ e atualizado com as publicações europeias contendo estudos da psicologia clássica, Afonso Henriques de Lima Barreto registra, em seus cadernos de anotações - Retalhos - e em Diário íntimo, observações da leitura da obra de Jules de Gaultier sobre o bovarismo, publicada em 1902, na mesma proporção em que há muitas referências rápidas a autores como Maudsley, o próprio Taine, seu sucessor Th. Ribot, psicólogo, que publicou Essai sur l'imagination créatrice, entre muitos outros.

Seria mesmo Recordações do escrivão Isaías Caminha um equívoco estético, a meio caminho entre a ficção e o relato íntimo?

\section{PREFÁCIO, ÍNDICE DE AUTOFICÇÃO?}

Até a primeira metade do século xx, o romance de Lima Barreto foi lido como uma espécie de autobiografia mal resolvida ou de romance com sérios problemas formais na sua constituição, como exemplifica a crítica de Lúcia Miguel Pereira, nos anos 1940:

Sugerindo mais do que dizendo, insinuando as sensações para só depois contar claramente o fato que as provocara, Lima Barreto mostrou possuir, neste primeiro romance que publicou, o segredo da narrativa psicológica; a arte de tornar os sucessos menos importantes do que a sua repercussão. [...] Mas para nosso prejuízo, Isaías entrando para a redação do Globo, muda repentinamente o rumo da narrativa, que de introspectiva passa a caricatural e se perde em minúcias de reportagem. [...] Foi o temperamento do romancista que se deixou, do meio para o fim do Isaías Caminha, dominar pela atitude personalista de Lima Barreto. ${ }^{23}$

22. Há inúmeras referências diretas do diálogo intenso de Lima Barreto com Nietzsche, presentes em crônicas, contos e diários. Referências indiretas encontram-se em seus principais romances.

23. Pereira, L. M. "Lima Barreto". In: houaiss, A.; figueiredo, C. L. N. Triste fim de Policarpo Quaresma/Lima Barreto. Madri: ALlCA xx, 1997 (Coleção Archives-Unesco), p. 451.

148 • FIGUEIREDO, Carmem Lúcia Negreiros de. Lima Barreto e o romance... 
Outros críticos buscaram investigar a obra, depois dos anos 1940, como Osman Lins, que, em Lima Barreto e o espaço romanesco, de 1976, ${ }^{24}$ exclui a dimensão biográfico-ideológica para elucidar a estrutura formal, o espaço romanesco, e considera marca da prosa ficcional de Lima Barreto a ausência de conflito, em virtude da dissociação entre seus personagens. Nessa perspectiva, a passividade do personagem Isaías é consequência da indefinição da voz narrativa, segundo o crítico, também desligada da trajetória dos demais personagens, o que constitui a modernidade de seus romances.

Por sua vez, Antonio Arnoni Prado enfatiza, em Lima Barreto: o crítico e a crise e em seus muitos outros artigos e ensaios, a singularidade do autor num estilo que ridicularizou o parnasianismo de Coelho Neto. Para o crítico, viu-se com Lima Barreto "que o fluxo narrativo cedia lugar ao tom improvisado que misturava reportagem e testemunho, aproximando-se da reprodução quase instantânea que se multiplicava ao ritmo das coisas em movimento". 25

O romance de estreia de Lima Barreto anuncia em seu título o percurso linear da vida do protagonista, desde a sua chegada, quando jovem, à cidade do Rio de Janeiro até sua promoção a redator de um importante jornal e, depois, a político. O leitor incomoda-se diante de um final que não traz um apaziguamento e uma conclusão a essa trajetória do narrador. Sabe-se, no prefácio, a última informação sobre a vida do protagonista, cuja contínua insatisfação e inquietude não permitem uma resposta clara: foi bem-sucedido? Foi feliz?

O prefácio realiza um movimento de duplicação, com um texto dentro de outro a produzir, simultaneamente, um desdobramento e a naturalização do processo de rememorar. Esse movimento no prefácio é projetado sobre todo o romance, de maneira especular, com o auxílio de um narrador-autor à margem da trama. A voz intrusiva do autor está presente no prefácio, apresentando trama e personagem, e discutindo os desdobramentos da ação a narrar. Temos, assim, uma espécie de intriga secundária: a do autor e seu processo de narrar, com os recursos escolhidos para tornar seu relato convincente, além do histórico das edições da obra, com todos os seus percalços.

Essa fabulação do autor, presente no prefácio, estende-se de maneira difusa pelo romance, de modo que Isaías Caminha se torna o autor anunciado das memórias e Lima Barreto, o seu escrivão.

24. LINS, O. Lima Barreto e o espaço romanesco. São Paulo: Ática, 1976.

25. PRAdo, A. A. Lima Barreto: o crítico e a crise. Rio de Janeiro: Cátedra; Brasília: INL, 1976, p. 527. 
Se, na ficção brasileira mais recente, observa-se a "presença autobiográfica real do autor empírico em textos que por outro lado são ficcionais", ${ }^{26}$ no romance de Lima Barreto, do início do século $\mathrm{xx}$, percebe-se a fabulação do eu do autor em uma espécie de "autoficção intrusiva", ${ }^{27}$ num movimento que cria paradoxos semânticos, porque não permite a tentativa de inscrever-se o confessional e a confidência, mas traz a presença do autor, como uma voz solitária que corre paralela à trama e ao cenário da narração, dramatizando a si mesmo e seu processo de narrar e seduzir seu público.

Quando comecei a publicar, na Floreal, uma pequena revista que editei, pelos fins de 1907, as Recordações do meu amigo, Isaías Caminha, escrivão da Coletoria Federal de Caxambi, Estado do Espírito Santo, publiquei-as com um pequeno prefácio do autor. Mais tarde, graças ao encorajamento que mereceu a modesta obra do escrivão, tratei de publicá-la em volume.

O meu amigo e camarada Antonio Noronha Santos, indo à Europa, ofereceu-se para arranjar, em Portugal, um editor.

João Pereira Barreto recomendou-me aos Senhores A. M. Teixeira \& Cia., livreiros em Lisboa, com a Livraria Clássica de lá; e elas foram impressas sob as vistas dedicadas do Senhor Albino Forjaz de Sampaio, a quem muito devem, em correção, as Recordações.

A todos três, não posso, em nome do meu querido Isaías, deixar de agradecer-lhes mais uma vez o serviço que prestaram à obra.

$\mathrm{Eu}$, porém, como tinha plena autorização do autor, por ocasião de mandar o manuscrito para o prelo, suprimi o prefácio, a donné, que agora epigrafa estas linhas, e alguma cousas mais.

O meu intuito era lançar o livro do meu amigo, sem escora ou para-balas.

26. MORICONI apud KLINGER, D. Escritas de si, escritas do outro: o retorno do autor e a virada etnográfica. 2. ed. Rio de Janeiro: 7 Letras, 2012, p. 12.

27. Nas tipologias de autoficção, Colonna (2012) caracteriza a autoficção intrusiva quando a transformação do escritor não acontece por meio da mediação de um personagem; seu intérprete não pertence à intriga propriamente dita, mas aparece como um apresentador, relator ou comentarista, em resumo: um narrador-autor à margem da trama. $O$ teórico apresenta como ilustração clássica da intrusão do autor no romance os parágrafos que abrem Pai Goriot (1834), de Balzac. colonnA, V. "Cuatro propuestas y tres deserciones (tipologias de la autoficción)”. In: CASAS, A. (Org.). La autoficción: reflexiones teóricas. Madrid: Arco Libros, 2012, p. 117. 
Assim foi. Hoje, porém, que faço uma segunda edição dele, restabeleço o original tal e qual o Caminha me enviou, pois não havia motivo para supressão de tanta coisa interessante que muito concorre para a boa compreensão do livro.

[...]

Como veem José Veríssimo disse estas palavras, logo ao aparecerem os primeiros capítulos; e, pensando serem verdadeiras as razões que expus, restabeleço o manuscrito como me foi confiado, passando a transcrever o prefácio inteiramente como saiu na inditosa Floreal. ${ }^{28}$

Se um prefácio consolida a obra e a explica, como afirma Lima Barreto, o de seu romance apresenta três tempos diversos, mas coerentes, de maneira semelhante ao que se vê no desenvolvimento da obra.

O primeiro tempo corresponde ao presente da publicação da segunda edição do romance - 1916 - , quando o autor comenta a recepção crítica aos primeiros capítulos surgidos na revista Floreal, que então ele dirigia, e, ainda, informa que já transcorreram dez anos, tanto da primeira publicação quanto da escrita dos manuscritos por Isaías Caminha, recurso que permite narrar os acontecimentos da vida do protagonista depois do ponto-final do romance.

O prefácio guarda, ainda, outro prefácio, o do pretenso autor das recordações, transcrito por Lima Barreto. Nele, aparece a justificativa para a escrita das memórias, que data de 1905 e marca um segundo tempo. O terceiro tempo, ainda no prefácio, trata do passado do escrivão Isaías, retomado por imagens sínteses, a partir de reflexões, de sua trajetória anterior a 1905.

Um prefácio composto de fragmentos de escritas - de autor e personagem narrador - com tempos diversos anuncia o movimento do livro, a se constituir como uma espécie de montagem. Entre esses tempos, ficam as imagens marcantes dos estados psicológicos do protagonista, feitas de névoa, sinais místicos e com a imprecisão do claro-escuro, como frágil elo dessa narrativa que se organiza, pela montagem de fragmentos de memória, diante do leitor. Nesse processo, o protagonista raramente vislumbra o sol a pino, tampouco um céu fartamente iluminado; consegue, apenas, contemplar "uma nesga do céu", um "rasgão irregular".

No decorrer da obra, a memória do narrador intercala tempo e espaço, num constante vaivém entre passado e presente, a saber: a trajetória do narrador quando

28. lima barreto, A. H. Recordações do escrivão Isaías Caminha. São Paulo: Ática, 1990, p. 15. 
jovem; o presente do protagonista, permeado dessas lembranças, que se tornam, aos poucos, as memórias ou recordações escritas; e o presente do autor, que apresenta o romance dez anos depois dos acontecimentos nele relatados.

Somos levados, por uma narrativa em primeira pessoa, aos primeiros anos da juventude de Isaías, sua origem e formação diante do espetáculo de saber do pai e da simplicidade da mãe, praticamente analfabeta, até o capítulo IV, quando a narrativa se intercala com longos períodos de reflexão do protagonista para expressar profundo desalento, angústia e solidão. A força dessas lembranças causa no presente do narrador muito sofrimento: "[...] depois de tantos anos de desgostos dessa relação contínua pela minha luta íntima, precocemente velho pelo entrechoque de forças da minha imaginação desencontrada, desproporcionada e monstruosa [...]".29

Envolvidos pelos acontecimentos da juventude de Isaías, recém-chegado ao Rio de Janeiro, para onde foi em busca do título de doutor, encontramos ao final do capítulo IV uma série de referências que permitem, simultaneamente, refletir sobre a finalidade do romance e seu diálogo com a tradição.

\section{DIÁLOGO COM A TRADIIÇ̃̃O: INFLUÊNCIAS?}

Há muitas referências a diversas obras no romance, entre elas, há a referência, num momento de angústia, abandono e solidão na cidade grande, ao livro que fora o guia de cabeceira do protagonista: "[...] o Poder da vontade, com as suas biografias heroicas: Palissy, Watt, Franklin... Sorri satisfeito, orgulhoso; havia de fazer como eles" ${ }^{30}$ Ao voltar à leitura do jornal, o personagem lê enormes elogios ao padeiro Manuel Laje da Silva, apresentado como de conduta e reputação duvidosas: "Que acontecera? Recebera a bênção papal até a décima quinta geração. A notícia vinha cheia de gabos à sua atividade e à sua honestidade [...] ".31 Uma interessante situação: a referência exemplar aos vencedores citados no livro, pelo mérito e talento, justaposta à notícia de jornal, que aplaude a reputação duvidosa.

A crítica, muitas vezes, associou essa obra a outros romances importantes do século XIX, quer pela afinidade dos temas, quer pelas referências explícitas feitas pelo

\footnotetext{
29. Id., p. 46.

30. Id., p. 48.

31. Id., ibid.
} 
narrador a $O$ vermelho e o negro, de Stendhal (1830), à obra $A$ educação sentimental, de Flaubert (1869), ou ainda a Ilusões perdidas (1839) e Pai Goriot (1834), de Balzac. Entretanto, se, tal como em Balzac, percebemos em Lima Barreto a representação do cotidiano banal, feio e prático, por meio da mistura de estilos, ${ }^{32}$ no caso do romance de Stendhal, o escritor dialoga com a crítica possível à relação existente entre pensar, sentir e fazer, sendo que a reflexão sobre a melhor maneira de agir não implica uma ação eficaz e coerente. Já de Flaubert, Lima Barreto assimila o interesse em projetar, na forma literária, os impasses, dilemas e fracassos do protagonista.

Após recordar-se de um momento de humilhação na juventude, o narrador afirma: "Hoje que sou um tanto letrado sei que Stendhal dissera que são esses momentos que fazem os Robespierres. ${ }^{\prime 3}$ A referência a Stendhal produz, em muitos leitores, a lembrança ou o diálogo de Lima Barreto com o escritor francês, como se o seu romance constituísse também uma narrativa semelhante à do romance europeu, mas repleto de problemas estéticos de realização, ao relatar a história de um jovem em busca de ascensão, prestígio e poder.

Em $O$ vermelho e o negro, acompanhamos a trajetória de Julien Sorel em seu aprendizado e ascensão, da plebe à burguesia provinciana e à aristocracia, visualizadas na imagem das duas carreiras, a eclesiástica e a das armas. Menos interessado nos fatos em si, Stendhal prioriza os efeitos dos acontecimentos sobre os sujeitos e vice-versa. O leitor encontra-se, por isso, com o drama interior do jovem Julien Sorel - o confronto de seus desejos e medos com os acontecimentos e a representação destes sobre ele -, tendo a história da França como pano de fundo. A síntese desse processo pode estar na expressão do protagonista na prisão: "Uma efêmera nasce às nove horas da manhã nos longos dias de verão, para morrer às cinco horas da tarde, como haveria ela de compreender a palavra noite?".34

A frase insere-se num momento crucial da narrativa, considerado um problema formal devido à incoerência ou falha no encaminhamento da ação do protagonista. Depois de conseguir sair da província e do seminário rígido e sombrio, Julien alcança êxito nos salões da aristocracia, conquistando a orgulhosa Mathilde, que dele engravida. Tal fato obriga seu pai, o poderoso Sr. de La Mole, a aceitar o casamento e conseguir para Julien uma patente

32. Auerbach, E. “Na mansão de la Mole". In: Mimesis. 2. ed. São Paulo: Perspectiva, 1987, pp. 405-41.

33. Lima barreto, A. H., op. cit., p. 48.

34. Stendhal. O vermelho e o negro. Trad. Souza Júnior e Casemiro Fernandes. São Paulo: Abril Cultural, 1979, p. 482. 
militar, forjando-lhe a condição de nobre. Quando tudo sugere calmaria, a sua trajetória sofre terrível reviravolta: uma carta da antiga amante da província, denunciando sua frieza e interesse ao Sr. de La Mole, faz Julien perder a cabeça e voltar à província de onde saíra, para tentar matar a ex-amante. O tiro não a mata, mas Julien é preso e condenado. Enquanto todos se empenham em salvá-lo, durante o julgamento, Julien opta por fumar caros charutos importados, recusando-se a agir em defesa própria. "Ele passava aqueles últimos dias a passear no estreito terraço no alto do torreão, fumando excelentes charutos que Mathilde mandara buscar na Holanda por um postilhão [...]." ${ }^{35}$ Em outras palavras, ação absolutamente contrária ao perfil obstinado, persistente e racional de Julien Sorel e aos efeitos esperados na concatenação das ações e arranjo de eventos.

Considerado marco importante na representação da realidade na literatura ocidental, o romance de Stendhal apresenta a crítica a certo padrão de associação entre pensar, sentir e fazer. Para Rancière, ${ }^{36}$ o planejamento sobre o melhor ato não resulta na capacidade de tomar uma decisão racional e implementá-la também. Nesse sentido, o fazer nada do plebeu Julien Sorel indica, ainda, a nova distribuição do sensível, segundo o crítico, o compartilhamento da igualdade sensorial por uma classe a que antes era impossibilitado o direito ao ócio como devaneio.

A divisão no cerne da ação e a escolha do ócio por Julien Sorel representam o direito ao devaneio e traduzem a expressão da crise do modelo napoleônico, ou estratégico, de ação. Para Rancière, o vazio do devaneio torna-se possível, na ficção, às almas das classes baixas.

Os ecos de Napoleão e o modelo de "grande homem" também chegaram a Isaías na sua fase de formação, por meio do discurso eloquente de seu pai. No entanto, ao jovem ficaram, apenas, "a entonação de voz, o gesto e o olhar". ${ }^{37}$ Mas como dialogaria o romancista brasileiro com a poderosa imagem de $O$ vermelho e o negro?

Há, sem dúvida, pontos em franco diálogo. Primeiramente, o desejo de investigar a complexidade dos motivos que conduzem os sujeitos; depois, a expressão de crise na linearidade da narrativa, mais precisamente no encadeamento de ações com base num modelo estratégico e racional, e, ainda, a reflexão sobre o poder da leitura como

35. Id., p. 458.

36. RANCIÈRe, J. "O efeito de realidade e a política da ficção". Trad. Carolina Santos. Novos Estudos CEBRAP, São Paulo, n. 86, pp. 75-90, mar. 2010.

37. LIMA barReto, A. H., op. cit., p. 19.

154 • FIGUEIREDO, Carmem Lúcia Negreiros de. Lima Barreto e o romance... 
propulsora de conhecimento e autoconhecimento, tema caro à produção romanesca de Lima Barreto.

\section{ISAÍAS - FABULAÇÃO DA CONSCIÊNCIA}

Recordações do escrivão Isaías Caminha concentra-se no drama íntimo da consciência do protagonista, por meio do velho recurso da onisciência do narrador, com o ponto de vista em primeira pessoa. Ainda que fartamente entremeado de narrações dos acontecimentos culturais e políticos que rodeiam o protagonista, é a representação da consciência do personagem, na sua vida interior, diante do confronto consigo mesmo e com a sociedade, o ponto forte dessas recordações. $\mathrm{O}$ movimento da consciência recebe certa ordenação do narrar mesclado a associações imaginativas, no espaço entre as reminiscências e o presente da narrativa.

Escrevendo estas linhas, com que saudades me não recordo desse heroico anseio dos meus dezoito anos esmagados e pisados! Hoje... É noite. Descanso a pena. No interior da casa minha mulher acalenta meu filho único. A sua cantiga chega-me aos ouvidos cheia de um grande acento de resignação. Levanto-me e vou à varanda. A lua, no crescente, banha-me com meiguice, a mim e a minha humilde casa roceira. [...] Correm alguns instantes; ela cessa de cantar e o brilho do luar é empanado por uma nuvem passageira. Volto às minhas reminiscências: vejo o bonde, a gente que o enchia, os sofrimentos que me agitavam e a rua transitada $[\ldots] \cdot .^{38}$

A melancolia e a dor contaminam o narrador no presente, enquanto escreve suas memórias; melancolia e impotência de quem se arrasta, enquanto registra suas lembranças. $\mathrm{O}$ estado psicológico do narrador das memórias e o do personagem quando jovem coadunam-se, portanto, e são visualizados na imagem frequente em todo o romance. "Nuvens plúmbeas já de todo tinham coberto a nesga do céu vista pela janela. Havia como que fuligem na atmosfera e a luz do sol tornara-se de um amarelo pardacento e fúnebre." ${ }^{39}$

38. Id., p. 48.

39. Id., p. 52. 
Dessa maneira, o mal-estar que acomete o jovem Isaías, após ser suspeito de roubo, intimado a comparecer a uma delegacia e chamado de "mulatinho" pelo delegado, é o mesmo sentimento de Isaías narrador, adulto, relembrando aqueles dolorosos momentos para escrever suas memórias. "Despertei hoje cheio de um mal-estar que não sei de donde me veio. Nada ocorreu que o determinasse. [...] Penso - não sei por que - que é este meu livro que me está fazendo mal [...]." ${ }^{\circ 0}$ Nesse sentido, a temporalidade escoa no romance, com o passado projetando-se sem cessar sobre o presente.

No entanto, há momentos de interessante alternância de estados emocionais do jovem Isaías, que são explicados pelo narrador mais maduro, posteriormente. Exemplo disso é a cena em que, na delegacia, demonstra solidariedade à dor e ao desamparo de uma jovem lavadeira, protagonista de uma briga banal de vizinhas, moradoras, ambas, de uma casa de cômodos.

As palavras saíam-lhe animadas, cheias de uma grande dor, bem distante da pueril querela que as provocara. Vinham das profundezas do seu ser, das longínquas partes que guardam uma inconsciente memória do passado, para manifestarem o desespero daquela vida, os sofrimentos milenares que a natureza lhe fazia sofrer e os homens conseguiram aumentar. Senti-me comunicado de sua imensa emoção; ela penetrava-me tão fundo que despertava nas minhas células já esquecidas a memória enfraquecida desses sofrimentos contínuos que me pareciam eternos; e achando-os por debaixo das noções livrescas, por debaixo da palavra articulada, no fundo de minha organização, espantei-me, aterrei-me, tive desesperos e cristalizei uma angústia que me andava esparsa. ${ }^{41}$

A solidariedade à dor alheia - que é também sua - acentua os traços de inquietação e angústia, marcas do personagem quando jovem e quando adulto, como narrador; solidariedade que expressa a percepção de um sentimento de humanidade, muito além da simples subjetividade. Novamente, a expressão de mal-estar acompanha-se do movimento da natureza: "A ela e ao meu abalo moral, juntavam-se a tonalidade amarelaça da tarde e o ambiente de forja para me dar um mal-estar nunca sentido". ${ }^{22}$

40. Id., p. 56.
41. Id., p. 54.
42. Id., ibid.

156 • FIGUEIREDO, Carmem Lúcia Negreiros de. Lima Barreto e o romance... 
A apresentação do estado emocional do jovem Isaías logo se acompanha da explicação do narrador, maduro, que usa a referência literária para esclarecer o movimento da consciência. A narrativa de um estado psíquico, antes da verbalização, a partir de impressões e reflexões, demonstra uma preocupação maior com aquilo que se é, ou que se pode tornar, do que com o relato de acontecimentos exteriores.

Por aí, houve em mim o que um autor russo chamou a convulsão da personalidade. Todo eu me agitei, todo eu me indignei. Senti num segundo todas as injustiças que vinha sofrendo; revoltei-me contra todos os sofrimentos que vinha suportando. Injustiças, sofrimentos, humilhações, misérias, juntaram-se dentro de mim, subiram à tona da minha consciência, passaram pelos meus olhos e então expectorei as sílabas: - Imbecil. ${ }^{43}$

Os incidentes constituem motivos para a introspecção e o autoconhecimento, incidentes que ocorrem num único dia, que começara com a observação do desfile de uma fanfarra militar em que "os oficiais pareceram-me de um país e as praças de outro. Era como se fosse um batalhão de sipaios ou de atiradores senegaleses". ${ }^{4}$ Depois do desenrolar de uma série de decepções e injustiças, a culminância de reflexões sobre o contexto cultural, mescladas a sentimentos íntimos, vem na ironia: "As lágrimas correram-me e eu pensei comigo: A pátria!"” 45

No romance, não é a ação, portanto, que predomina, e todos os acontecimentos realizam-se no perscrutar das lembranças e dos pensamentos do protagonista. Os aspectos cronológicos, culturais e históricos constituem elos entre os dois momentos, o vivido e o narrado, e apenas reforçam a complexidade temporal da narrativa.

Do capítulo viI, quando inicia a trajetória de Isaías na imprensa, até o capítulo XIV, o último do romance, as mesmas reflexões e estado psíquico do protagonista quando jovem e quando memorialista - permanecem, com um misto de angústia, impotência, desolação e, acima de tudo, solidão, mesmo depois de bem empregado como redator de importante jornal.

No último capítulo do romance, há sinais claros de ascensão social do protagonista: "Dois meses antes era simples contínuo, limpava mesas, ia a recados de todos;

43. Id., p. 55 .

44. Id., p. 38 .

45. Id., p. 55 . 
agora, poderosas autoridades queriam as minhas relações e a minha boa vontade". ${ }^{46}$ No entanto, há também índices de transformação interior, como a capacidade de reagir com violência às ofensas e humilhações. Assim, diante da provocação de um colega jornalista, Isaías reage com violência e força: "Senti-me outro, muito mais forte, transtornado e desejoso de matar" ${ }^{47}$ Portanto, da convulsão interior e do balbucio do jovem recém-chegado à capital, na delegacia, no capítulo viI, ao agora orgulhoso jornalista.

Encontrei o tal repórter na Rua Primeiro de Março e antes que ele fizesse o menor movimento atirei-me sobre o seu corpanzil, deitei-o por terra e dei-lhe com quanta força tinha. Na delegacia, a minha vontade era rir-me de satisfação, de orgulho, de ter sentido por fim que, no mundo, é preciso o emprego de violência, do murro, do soco, para impedir que os maus e os covardes não nos esmaguem de todo. ${ }^{48}$

Apesar do dinheiro, das pândegas, da sensação de domínio e controle, o reencontro com um cenário de interior - casas pobres, com quintais, em região rural - provoca no protagonista a reflexão de que não avançara, pessoalmente, em nada com relação a seus sonhos. Na sua viagem do interior para a cidade, seu estado psíquico desmanchase em apatia e dilacerações, numa angústia contínua do sujeito alquebrado diante das dificuldades externas.

Fomos servidos em velhos pratos azuis com uns desenhos chineses e as facas tinham ainda aquele cabo de chifre de outros tempos. À vista deles, dos pratos velhos e daquelas facas, lembrei-me muito da minha casa, e da minha infância. Que tinha eu feito? Que emprego dera à minha inteligência e à minha atividade? Essas perguntas angustiavamme. [...] Lembrava-me de que deixara toda a minha vida ao acaso e que não a pusera ao estudo e ao trabalho com a força de que era capaz. Sentia-me repelente, repelente de fraqueza, de falta de decisão e mais amolecido agora com o álcool e com os prazeres... Sentia-me parasita, adulando o diretor para obter dinheiro. ${ }^{49}$
46. Id., p. 135.
47. Id., p. 136.
48. Id., ibid.
49. Id., pp. 142-3. 
$\mathrm{Na}$ avaliação de sua vida, restam ao personagem frustração e dor: "Sentia-me sempre desgostoso por não ter tirado de mim nada de grande, de forte e ter consentido em ser um vulgar assecla e apaniguado de um outro qualquer. [...] Por que o tinha sido? Um pouco devido aos outros e um pouco devido a mim".50

O escrivão Isaías, ao escrever suas memórias, reconhece que não é mais tempo de ler nos astros o destino dos homens - "A nossa humanidade já não sabe ler nos astros os destinos e os acontecimentos" ${ }^{\prime 1}$-, embora, na sua juventude, tenha se guiado por sinais, como o movimento de aves no céu, que formavam um $V$ indicando, na sua interpretação, um "vai", estímulo para deixar o interior e tentar a vida na capital.

\section{A IMPRENSA — ESPAÇO E ESCRITA}

O espaço de maior tensão e confronto para Isaías Caminha é o dos bastidores da imprensa, espaço ambicionado por um jovem intelectual. No romance, é um ambiente avesso à criatividade crítica, à produção intelectual, mas propício à manutenção das aparências de saber, à ostentação de poder e subserviência, por meio de manchetes sugestivas, achados anedóticos e leveza na paginação.

Por centralizar a administração federal, a cidade do Rio de Janeiro afirma-se como o maior mercado consumidor brasileiro, tendo sido fortemente beneficiada por programas de obras para reformas e modernização, possíveis graças ao grande afluxo de capitais estrangeiros entre 1903 e 1913. A necessidade de solução dos problemas básicos da cidade, como a falta de água, melhores condições de saúde, transporte e moradia, é abandonada para favorecer a construção de uma imagem por meio de projeto urbanístico que tem em Paris o seu modelo político e metodológico.

A vida literária caracteriza-se pela decadência do folhetim, com os jornais exigindo crônicas mais curtas e vivas; além disso, há o emprego mais generalizado da entrevista e da reportagem, com o lápis do caricaturista gradualmente substituído pelo fotógrafo. ${ }^{52}$ Como mercadoria, dá-se com a informação o mesmo que com os objetos - segue indiretamente as fantasmagóricas e sedutoras características da moda. Daí a

50. Id., p. 143 .

51. Id., ibid.

52. Broca, J. B. A vida literária no Brasil - 190o. 2. ed. Rio de Janeiro: José Olympio, 1960. 
busca do sensacional, a dramatização dos fatos do cotidiano, a fabricação de ídolos e vedetes para mostrar o inesperado, curioso e até trágico, garantidos pelo tom da escrita, a qual precisa aproximar-se da imagem, desde a leveza da paginação a manchetes sugestivas e achados anedóticos.

Na sociedade brasileira, porém, a longa permanência da comunicação oral e, por isso, a ausência de libelos escritos, bem como a predominância da crítica personalista, da pilhéria, da anedota, do dito ao pé do ouvido no lugar de uma observação dirigida às instituições e não às pessoas, moldaram a imprensa e suas relações com a sociedade. Além dos textos a pedidos e anônimos com críticas contundentes e ataques pessoais, a estrutura jornalística manteve-se oligárquica, paternalista, equilibrando-se entre $o$ latifúndio poderoso, da Primeira República, e a burguesia urbana em ascensão, mas politicamente frágil. ${ }^{33}$ Por isso, à forma espetacular de fatos, imagens e técnica unemse os valores tradicionais, depositados no imaginário e em movimento no dia a dia, como, por exemplo, o arranjo, o saber de fachada e título, o sentimentalismo, o fascínio pelo futuro e a imprevisibilidade na organização do presente. Por mais contraditório que pareça, as qualidades da informação - baseada na fatualidade, na cientificidade instantânea e nas novidades que resultam num saber frágil, superficial e fragmentário - coadunam-se com as nossas características culturais.

O protagonista contamina-se daquele ambiente, que também projeta suas teias sobre sua vontade, desejo e autonomia. Observa-se a vinculação, e coerência, com a primeira parte do romance, porque o autor não opta pelo cômico, pela distância e pela superioridade, mas escolhe a proximidade, que permite a crítica. A estratégia da sátira inclui a reflexão, feita pelo próprio Isaías, e, no romance, apresenta-se, além do ridículo, a consciência do ridículo. O mundo da imprensa, da política, do poder e do espetáculo não é somente representado como distorcido, mas também é analisado e comentado.

A proximidade do autor com o leitor e a quebra da distância crítica - o rompimento com a lei da causalidade e da escrita triunfante para narrar a trajetória do jovem protagonista - constituem interessantes estratégias para a crítica à perspectiva realista

53. Em Trincheiras de sonho: ficção e cultura em Lima Barreto, é desenvolvido um estudo sobre a imprensa, no Brasil da Primeira República, junto à análise do romance Recordações do escrivão Isaías Caminha, que apresenta a palavra no mercado e no centro de poder, a produzir ilusões e fantasmagorias, debaixo de luzes típicas de espetáculo. Figueiredo, C. L. N. Trincheiras de sonho: ficção e cultura em Lima Barreto. Rio de Janeiro: Tempo Brasileiro, 1998.

160 • FIGUEIREDO, Carmem Lúcia Negreiros de. Lima Barreto e o romance... 
na concepção da narrativa, inserindo dúvidas e inquietações sobre o narrar, além do movimento não linear na exposição dos acontecimentos diversos, realizando uma montagem ou justaposição de tempos, espaços, estados de alma e situações.

Revela-se o caráter de ilusão da escrita como transparente e precisa no registro das emoções e vicissitudes das experiências dos sujeitos; a escrita torna-se espaço de confrontação de diferentes paixões, emoções, interesses e pluralidades de "eus" que formam a subjetividade. Isso representa profunda crítica à ideia da essência lógica e racional da subjetividade e de uma escrita capaz de transcrevê-la.

As divisões, no texto, entre tempos e falas diversos (autor, narrador e personagem) sugerem também uma coexistência nem sempre harmônica entre os diversos sentidos que constroem afetiva e culturalmente o "eu", num contexto social. Daí a escrita não poder ser o registro de recursos e estratégias de um sujeito que expõe, de forma estável e segura, seu processo de conhecimento e autoconhecimento, uma vez que a identidade, no romance, não é pensada como algo fixo e permanente. A escrita é o espaço de experiência desse sujeito, com uma relação tensa, múltipla, instável consigo mesmo e com o mundo.

\section{NOVA MOLDURA PARA O ROMANCE}

Quais são as consequências dos aspectos formais aqui elencados para o romance, para as memórias que Isaías escreve?

Há uma forte presença de elementos formais que alteram significativamente $o$ princípio épico. Se, no romance do século XIx, a abordagem psicologizante é mediada pelo narrador (à exceção de Flaubert), recursos como o monólogo interior garantem, ainda, a distância épica. Em Recordações do escrivão Isaías Caminha, a interiorização retira do tempo presente e real e da ação sua importância como princípio formal, o que expressa a crise do romance na tentativa de mostrar a diminuição da perspectiva, isto é, da distância crítica para representar o mundo e os sujeitos.

O fluxo da vida psíquica absorve o mundo, que, por sua vez, traz as marcas do sujeito, que não tem mais a certeza da consciência privilegiada, para, a partir dela, constituir uma realidade ou narrar uma história. A voz gramatical - o eu do narrador não revela distância, ou superioridade, e indica que ainda faz parte dos acontecimentos narrados, uma vez que as dores e inquietações são comuns ao narrador, adulto e amadurecido, e ao jovem, personagem das memórias. O discreto embate entre as vozes do 
autor, do eu narrador e do personagem é índice forte da consciência metaficcional sobre o narrar e da consciência da incompletude ou insuficiência de sentido para a existência.

Nesse aspecto, há o constante questionamento acerca da eficácia da linguagem para realizar tal comunicação, por meio do narrador Isaías: "Se me esforço por fazê-lo literário é para que ele possa ser lido, pois quero falar das minhas dores e dos meus sofrimentos ao espírito geral e no seu interesse, com a linguagem acessível a ele".54 Já entre o desejo, o pensamento e a linguagem, não há transparência e certeza, mas suspeita e insegurança quanto ao narrar, como questiona Isaías: "Quem sabe se ele me não vai saindo um puro falatório??.55 Boa parte dos fatos narrados diz respeito ao íntimo do protagonista; as humilhações, frustrações e perdas ainda estão no presente, na alma do narrador, o que elimina a visão perspectivística, estabelecendo à temporalidade uma duração, com a forte presença do passado no presente.

Todos os elementos formais explicitados até aqui são próprios do romance do século $\mathrm{xx}$ e inserem-se no âmago do romance que se anuncia, pelo título, como uma narrativa de perfil semelhante ao dos romances realistas do século xix. No entanto, a expectativa anunciada não se cumpre. Se a intenção do escrivão Isaías é produzir uma obra autobiográfica, espera-se, então, um aprofundamento do eu, com a finalidade de explicar as diferenças entre a subjetividade e o mundo, as causas da angústia que o dilacera pela não realização de seus sonhos. O sujeito buscaria, portanto, autoconhecimento e expressão pela exposição de si numa ordem narrativa e de uma perspectiva privilegiada; isso porque ninguém melhor do que o protagonista para responder às questões sobre sua identidade, sendo, por isso, capaz de demonstrar convicção e segurança na apresentação (e justificativa) dos fatos. Em outras palavras, estabeleceria a si mesmo como campo de observação e investigação. No entanto, as memórias de Isaías anunciam outras formas de falar de si.

Não se constitui, na obra, a perspectiva cartesiana de representação da subjetividade, numa escrita triunfante que teria como pressuposto a capacidade de selecionar critérios, estratégias e recursos persuasivos para projetar a si mesmo, de modo a levar ao receptor uma imagem de um sujeito capaz de compreender a natureza, as relações sociais e, principalmente, a si mesmo. Isaías Caminha não responde às perguntas sobre sua identidade, seu percurso de conhecimento e autoconhecimento; apenas formula

54. LimA BARreto, A. H., op. cit., p. 56.

55. Id., ibid.

162 • FIGUEIREDO, Carmem Lúcia Negreiros de. Lima Barreto e o romance... 
perguntas e as projeta para o leitor. Tampouco nele percebemos o sujeito com pretensão à verdade, num movimento de introspecção e autoexploração, isto é, uma proposta de conhecimento de si a partir da sensibilidade, na busca de transparência e completude na apreensão e registro de sentimentos e valores. Nem pela razão, tampouco pela sensibilidade: Isaías não demonstra conhecimento pleno de si e dos motivos de suas dores.

O processo de construção do sujeito, no romance, não é fechado, unitário, concluso, uma vez que as vozes dos outros - as pressões, impressões, injunções vindas dos outros constituem e moldam o sujeito, num cruzamento de forças, ou seja, a identidade forma-se no meio desse cruzamento de forças e interesses. Tal ideia de subjetividade também sugere que não existe um espaço e forma privilegiados de representação das próprias vivências, mas a escrita está em processo, com os outros, tanto quanto o sujeito. Assim, as oscilações do sujeito e as turbulências da forma do romance (prefácio com tempos e vozes diversos que se projetam na narrativa) coadunam-se, de maneira coerente. A escrita não é somente o relato das experiências vitais, ela mesma se torna uma experiência.

As consequências (ou a escolha) desse processo aparecem na forma do romance, uma espécie de montagem e justaposição de vozes narrativas que se evidencia desde o prefácio e estende-se por toda a obra, tendo como ponto culminante o último capítulo. Nele, o autor intervém, novamente, no discurso do personagem Isaías, como a quebrar o pacto ficcional com a fabulação do eu autoral, exatamente quando explana sobre os preconceitos acerca da capacidade intelectual de jovens pobres e mulatos, cujo exemplo é o protagonista.

[...] fiquei animado, como ainda estou, a contradizer tão malignas e infames opiniões, seja em que terreno for, com obras sentidas e pensadas, que imagino ter força para realizá-las, não pelo talento, que julgo não ser muito grande em mim, mas pela sinceridade da minha revolta que vem bem do Amor e não do Ódio, como podem supor. Cinco capítulos da minha Clara estão na gaveta; o livro há de sair... Penso, agora, dessa maneira; mas durante o resto do tempo em que estive no O Globo, quase me conformei, tanto mais que o interesse que o diretor mostrou por mim não foi nada platônico..$^{56}$

O romance contamina-se, então, de discurso autobiográfico, assim como o autobiográfico matiza-se de ficção. Esse processo relativiza os limites do ficcional e expõe os impasses da escrita, porque

56. Id., p. 136 . 
inserir alguma coisa (o discurso autobiográfico) noutra diferente (o discurso ficcional) significa relativizar o poder e os limites de ambas, e significa também admitir outras perspectivas de trabalho para o escritor e oferecer-lhe outras facetas do objeto literário, que se tornou diferenciado e híbrido. ${ }^{57}$

Há também referências ao leitor ("como podem supor"), sendo que a presença ou o desejo de interlocução fica mais evidente quando o narrador Isaías se refere às práticas jornalísticas dos colegas. Por exemplo, para explicar a adaptação feita por Leporace, um dos poucos jornalistas que ainda lia, de um trecho do romance de Daudet, ${ }^{58}$ Isaías convoca o leitor:

Os senhores lembram-se daquela passagem dos Reis no Exílio em que Colette de Rosen, cavalgando ao lado da rainha Frederica, atira-lhe indiretas referentes ao seu silêncio em face das infidelidades do marido? Lembram-se que a rainha, sentindo o golpe [...]. Pois bem. Leporace não teve dúvidas; agarrou a frase do diálogo e desenvolveu-a no seu estilo barroco, por quase uma coluna, do seguinte modo: [...].59

O mundo de Isaías Caminha (a imprensa, a cidade, os intelectuais e suas ações de poder) já não é somente um dado objetivo, mas está contaminado de suas impressões e angústias. Por outro lado, esse mundo exterior deixa suas marcas na alma do protagonista.

O escritor utiliza referências importantes do romance do século xıx, como a trajetória de formação do jovem, sua busca por êxito e realização social; a experiência urbana, tema significativo também ao romance modernista; e a proposta de "memórias", frequente nos títulos de romances da literatura brasileira. No entanto, utiliza princípios formais que já introduzem uma nova realização estética do romance. Produz, portanto, uma crise, a qual não quer dizer insuficiência de forma, fracasso ou má qualidade estética.

A crise, em primeiro lugar, é característica própria do romance, cujos aspectos, como a plasticidade e a autocrítica, garantem, segundo Bakhtin, ${ }^{60}$ a renovação do gênero.

57. Santiago, S. “Meditação sobre o ofício de criar”. Gragoatá, Niterói, n. 31, p. 17, 2011.

58. Os reis no exílio (Les rois en exile, 1878). Na Limana, nome dado por Lima Barreto à sua coleção de livros, aparece o registro da obra em francês. Note-se aí o cuidado do escritor para com o leitor de citá-la, no romance, em português.

59. LimA BARRETO, A. H., op. cit., p. 138.

6o. вакнtin, M. Questões de literatura e estética. Trad. Aurora Fornoni Bernardini et al. São Paulo: Hucitec; Unesp, 1988.

164 • FIGUEIREDO, Carmem Lúcia Negreiros de. Lima Barreto e o romance... 
Em segundo lugar, compreende-se a crise como a consciência crítica acerca da impossibilidade de narrar, de escrever um romance, ou "as memórias", nas primeiras décadas do século xx e em seu contexto cultural efervescente, com os mesmos recursos estéticos e formais do século anterior. A única maneira de continuar narrando seria contradizendo a forma da narrativa até então. Assim, na forma antiga (ou a esperada pelo leitor), inserem-se os novos elementos formais, como a temporalidade complexa, uma subjetividade flutuante e instável, a crítica à concepção da linguagem límpida e transparente em relação ao real e a contaminação do ficcional pelo autobiográfico. Todos esses aspectos formais renovam o romance, no início do século $\mathrm{xx}$, e alcançam os nossos dias.

Não há negação total do realismo no romance, negação esta que impossibilitaria seu grande objetivo e missão: tornar a literatura significativa para a reflexão e formação dos leitores. No entanto, há quebras constantes do pacto ficcional pela inserção direta da voz autoral, provocando uma identificação e reconhecimento por parte do leitor. Quebra-se um pouco a coerência da estrutura, isto é, a lei da causalidade na narrativa, não somente pelo fato de as explicações finais acerca da trajetória final do protagonista aparecerem no prefácio, mas também porque o encadeamento lógico, das motivações e das ações, é rompido: Isaías termina o romance como começou, ou seja, em deslocamento, insatisfeito, com seus sonhos intelectuais não realizados.

Há, também, um aprofundamento da perspectiva psicológica. Como vimos, a relativização da perspectiva temporal, por meio da justaposição de tempos distintos e do relato de tudo partir da consciência do protagonista, permite menor valorização da cronologia e dos acontecimentos externos. O mais importante é o resultado do tempo e das ações exteriores sobre a personalidade do sujeito. A corrosão da cronologia, da perspectiva temporal e do enredo está intimamente ligada à fluidez do sujeito, na imprecisão de seus contornos morais, na ausência de metas eficientes para alcançar seus objetivos. A crise anuncia, dessa maneira, uma nova forma de romance, uma nova concepção de subjetividade.

Recordações do escrivão Isaías Caminha é um romance realista que já aponta os limites do realismo, especialmente na apresentação da subjetividade, no questionamento do lugar do autor, na suspeita sobre a linguagem, na compreensão do tempo (e da memória) como construção do sujeito e da cultura e na crítica à estratégia de causalidade e racionalidade no desenvolvimento das ações. Na obra, o vaivém temporal e espacial e a subjetividade flutuante coadunam-se com a sensibilidade das primeiras décadas do século xx e Lima Barreto aproxima-se de seus contemporâneos intelectuais no fascínio em compreender o fluxo da vida e do sujeito, como exemplifica Pirandello: 
"O que nós conhecemos de nós mesmos não é senão uma parte, talvez uma pequeníssima parte daquilo que nós somos" ${ }^{61}$

Por isso, o romance pede nova moldura aos leitores críticos, aquela que toma como ponto de partida a crise do indivíduo e a força do espaço interior, que esvazia a objetividade e concatenação épicas, produto do processo de fragmentação e decomposição, sobretudo, do "eu", que se transforma numa multiplicidade de núcleos, relações e qualidades sem um centro unificador.

Paradoxalmente, o romance continua a cumprir a missão, tão cara ao escritor Lima Barreto, de ser um instrumento cognitivo privilegiado. Ensina aos leitores que não se pode mais narrar, como os autores do século XIX, a trajetória de jovens em busca de conhecimento e autoconhecimento sem provocar fissuras na forma tradicional do romance. Num momento de triunfo, e catástrofe, da vida moderna nas primeiras décadas do século $\mathrm{xx}$, Lima Barreto acima de tudo provoca os leitores ao dar movimento, no romance, ao sentido da expressão nietzschiana "Uma coisa sou eu, outra são meus escritos". ${ }^{2}$

Carmem Lúcia Negreiros de Figueiredo é Doutora em Teoria Literária pela Universidade Federal do Rio de Janeiro, Professora Associada de Teoria da Literatura da Universidade do Estado do Rio de Janeiro (UERJ) e Bolsista Prociência FAPERJ/UERJ. Autora de Lima Barreto e o sonho republicano (Tempo Brasileiro, 1995), Trincheiras de sonho: ficção e cultura em Lima Barreto (Tempo Brasileiro, 1998) e organizou, junto com Antonio Houaiss o volume Lima Barreto, da Coleção Archives/UNESCO(1997). Realizou pós-doutorado na USP, com bolsa PDS-CNPq, e tem no prelo o livro Lima Barreto, caminhos de criação.

61. Pirandello, L. O humorismo. Trad. Dion D. Macedo. São Paulo: Experimento, 1996, p. 159.

62. Nietzsche, F. Ecce homo. Como alguém se torna o que é. 2. ed. Trad. Paulo César de Souza. São Paulo: Companhia das Letras, 1995, p. 52. 